\title{
Assessment of Seismic Load Capacity of a Slender Masonry Clock Tower
}

\author{
Şahin Sözen ${ }^{1 *}$ \\ ${ }^{1}$ Department of Civil Engineering, Faculty of Engineering and Architecture, Tokat Gaziosmanpasa University, 60150, Tokat, Turkey \\ * Corresponding author, e-mail: sahin.sozen@gop.edu.tr
}

Received: 08 December 2021, Accepted: 01 February 2022, Published online: 10 February 2022

\begin{abstract}
The paper presents the seismic vulnerability assessment of a historical masonry clock tower by means of the finite element method. The mechanical behavior and failure mechanism of these structures must be well understood in order to evaluate their performance and select an appropriate retrofit approach when needed. Stone towers, which sometimes have complex geometries and irregularities and are often designed for vertical loads, are vulnerable to lateral loads, especially earthquake loads, due to the slenderness of the tower and the limited ductility of the stone. This study aims to determine the horizontal load capacity of a magnificent clock tower by investigating its structural behavior using the finite element method. The analyzes carried out considering the seismicity of the region showed that the clock tower would be severely damaged or completely collapsed in case of an earthquake with an exceedance probability of $10 \%$ in 50 years. In non-linear time history analyses, the maximum base shear force to weight ratio was calculated as 0.27 . The maximum drift ratio at the top of the clock tower reveals that the tower exceeds the collapse prevention performance level. The residual displacements obtained from non-linear time history analysis prove that plastic deformations occur on the tower body. In the light of this data, it is considered that the clock tower needs to be retrofitted with acceptable restoration procedures against possible earthquakes in the region.
\end{abstract}

Keywords

slender masonry tower, lateral load capacity, time history analysis

\section{Introduction}

Clock towers are not only among the important carriers of cultural heritage but are undoubtedly one of the most remarkable structures of all cities, modern and ancient. The tradition of clock towers began in Europe in the $13^{\text {th }}$ century and spread to the Ottoman Empire in the late $16^{\text {th }}$ century [1]. The first clock tower in Anatolia was built in Safranbolu in 1797 [2]. Even though some of them in Anatolia were built in a dominant place of the city or on a hill, clock towers, which are structures representing the central authority, were mostly built in the city center. There are clock towers in a building complex as well as those that are part of a building. In addition, there are clock towers that were created by adding a clock to an old factory chimney or a minaret. Although most clock towers are made of stone, there are also towers made of wood. In terms of functionality, in addition to displaying the time, there are clock towers used as fire and observatory towers, and clock towers displaying barometer and thermometer. Although there are many clock towers in Turkey today, the number of towers with remarkable features is one hundred and twenty-six [2]. The city with the most clock towers is Istanbul with twenty towers, followed by İzmir with seven towers [2].

Masonry is one of the most commonly used construction techniques in historic buildings of many countries around the world [3]. Among all the historic buildings that characterize the world's architectural heritage, ancient masonry towers are widespread throughout Europe and represent one of the most important elements of local cultural heritage $[4,5]$. The protection of historic masonry buildings from seismic impacts is crucial and strategic in many earthquake-prone countries. It should be noted that Turkey is a country with an extensive, ancient, and significant built heritage and unfortunately has a high seismic risk. Towers made of stone, sometimes with complex geometries and irregularities, often designed to resist vertical loads, can 
be considered vulnerable to lateral loads, especially earthquakes, due to the slenderness of the tower and the limited ductility of the stone [6,7].

It is well known that a large proportion of historic masonry buildings in the world are in regions of high earthquake risk. Therefore, it can be readily said that most of them are vulnerable and unsafe against earthquakes [8]. Although the structural analysis of historic buildings, including the evaluation of seismic behavior and seismic damage, is a challenging topic, such analyzes are of great interest to many researchers and engineers. Since the most effective way to preserve historic buildings is to accurately understand their structural behavior, important studies on this topic have been completed, especially in recent years [9-17]. Given their slenderness, esthetics, and symbolic value, it is undeniable that masonry towers attract special attention in research and engineering among all masonry structures. Shehu [18] focused on pushover analysis of masonry towers as a widely used approach in seismic assessment of all structures. The study, which investigated the influence of geometry, material properties, and loading patterns, addressed various approaches that can be used to design a nonlinear static analysis in any FEM software package. Azzara et al. [9] investigated the condition and damage scenario of the historic masonry bell tower adjacent to the Monza Cathedral using vibration testing. The effect of the construction technique on the seismic capacity of the old dry joint masonry was investigated by Pulatsu et al. [19] using discrete element method (DEM). de Silva [13] studied the influence of soil-foundation structure (SFS) interaction of different masonry towers placed on stiff to soft soil to resist earthquakes. Shehu [20] investigated three inclined historic masonry towers in the city of Ferrara (Northeast Italy) under seismic loads using advanced numerical models to evaluate seismic vulnerability. Bartoli et al. [11] investigated the role of openings along the façade of the towers in estimating the main frequency. Valente and Milani [21] studied the effects of geometric features on the seismic response of historic masonry towers as a continuation of two other papers $[22,23]$ by the same authors that focused on the seismic vulnerability assessment of masonry towers.

These types of magnificent structures must be well protected against devastating earthquakes. This study aims to determine the horizontal load capacity of a magnificent clock tower by pre-monitoring its structural behavior using the finite element method to protect it from possible earthquake damage.

\section{Structural features}

The Tokat Clock Tower, whose construction was completed in 1902, is located south of the Behzat Mosque in the Behzat district, known as the old city centre. The $33 \mathrm{~m}$ high tower is made of cut stone and has a muvakkithane (in Turkish). Muvvakkithane, in the past, was the place where prayer times were determined with various instruments and observations. The cornices on the body of the tower, an octagonal structure that tapers upwards from the square base, divide the structure into five floors. The tower, visible from almost any point in the city during the years of its construction and even today, has huge clocks on the top floor that point in all four directions. In 1917, the dials of these clocks were replaced and modernized. The main entrance to the building is through an arched iron door on the south side. There is a shop currently used as a clock repair shop on the west side of the tower. No structural damage was noted during on-site observations. An old photograph of the clock tower dating back to the 1900s and a current one are shown in Fig. 1.

The technical drawings of the clock tower, whose restoration project was completed in 2019, are by Seka Architecture [24]. The base, which includes the shop, is $5.8 \mathrm{~m}$ high and measures $5.6 \times 5.6 \mathrm{~m}$ square in plan. The staircase starts right next to the entrance on the south facade. The width of the staircase, which is supported by the exterior walls and a $20 \mathrm{~cm}$ thick hollow core with an external diameter of $2 \mathrm{~m}$ in the center, is $0.7 \mathrm{~m}$. The staircase, which consists of 106 monolithic stone steps, rises $0.22 \mathrm{~m}$ for each step. The core around which, the tower staircase spirals, continues to the balcony with the same dimensions. The floor plan at $+0.00 \mathrm{~m}$ and elevation of the tower can be seen in Fig. 2.

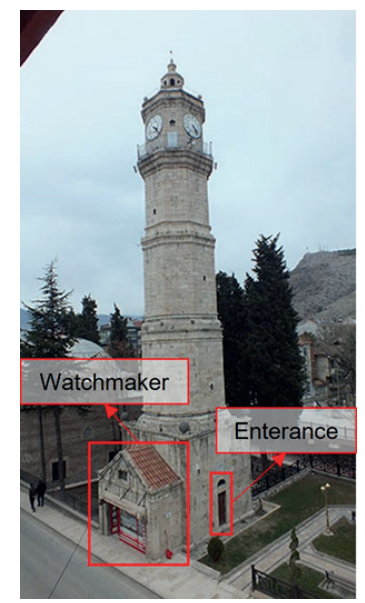

(a)

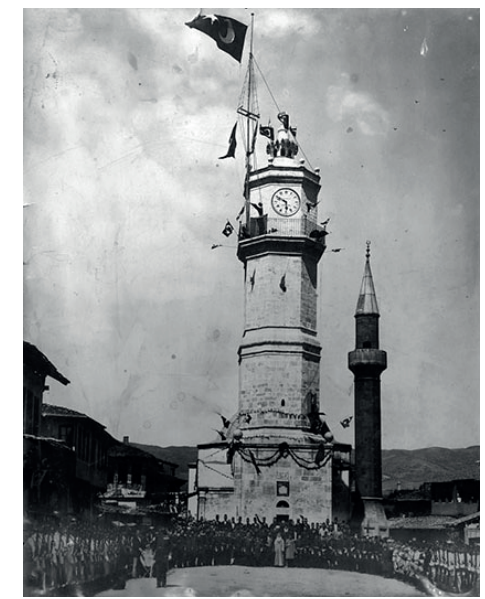

(b)
Fig. 1 Photos of the clock tower (a) Current photo, (b) An old photo [24] 


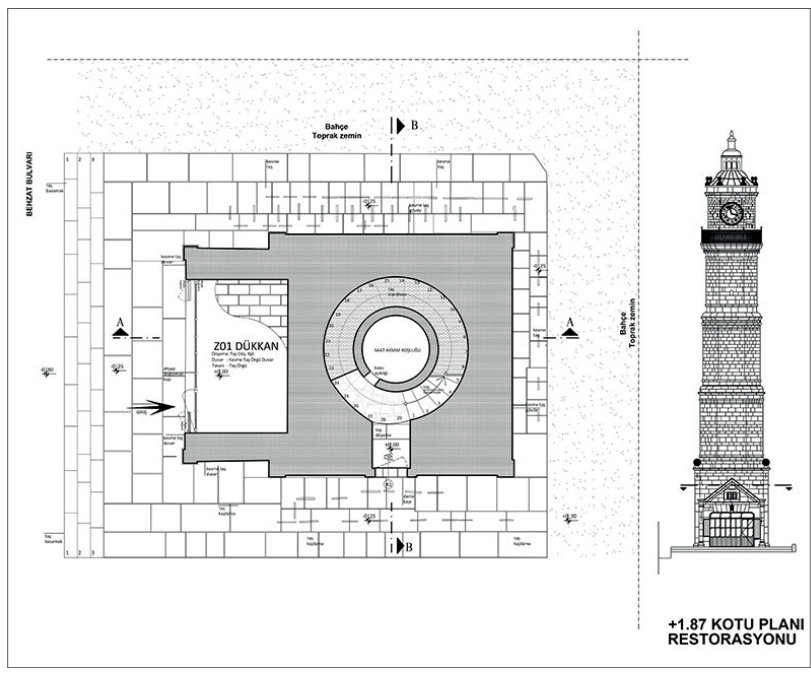

Fig. 2 Base plan and the elevation [24]

The tower consists of 4 separate octagonal sections rising above a square base. The dimensions of the octagons in the plan gradually decrease, creating a highly aesthetic form throughout the tower elevation. The side lengths of the octagons vary between 1.5 and $2 \mathrm{~m}$. Subtle architectural elements have been used to soften the transition between the octagonal blocks of varying sizes. The plan view at $+9.00 \mathrm{~m}$ and the wall section of the tower are shown in Fig. 3. There are 5 asymmetrically arranged openings of different shapes and sizes in the tower body. In the octagonal body where the clocks are located, there are 4 symmetrically designed openings and a door to the balcony.

\section{Structural analyses}

Structural assessment and intervention procedures for historic structures are of great importance to protecting them against earthquake damages. The non-linear finite

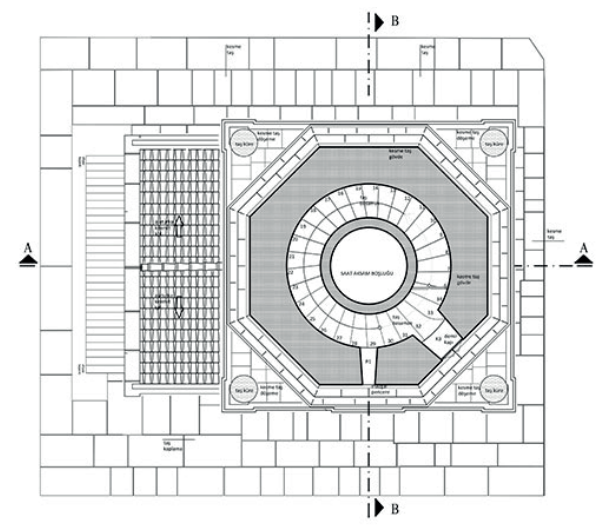

(a)

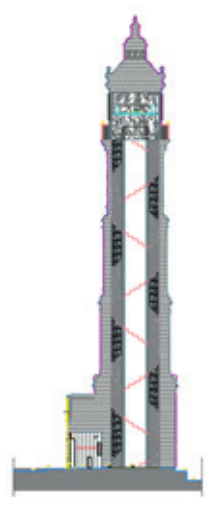

(b)
Fig. $3+9.00 \mathrm{~m}$ plan and section view of the tower (a) Plan view at +9.00 $\mathrm{m}$, (b) Wall section [24] element method offers engineers the possibility of evaluating historic buildings in detail before they are damaged. For this purpose, various numerical analysis methods are used by researchers to evaluate historic buildings [25].

\subsection{Finite element model}

Due to uncertainties such as boundary conditions, previous deformations, material properties, and material degradation, numerical analyzes of historic structures are difficult and the results may not be necessarily conclusive. The software used for the analysis should be sufficiently qualified to model and solve considering the above uncertainties and all details of the structure. In this study, the academic finite element software ANSYS [26] was used for the analyzes. The finite element and SolidWorks [27] models of the tower are shown in Fig. 4. The foundation of the tower was not included in the numerical model because no information was available about it and there was no research opportunity. Since the fixed base approach is widely used in the numerical analysis of masonry towers [20, 28-31], in this study fixed support was assumed at the bottom of the base, including the store. While the entire body is modeled as a homogeneous material, the thin architectural elements that form the transition between the octagonal blocks are not included in the model. The finite element model consists of 77360 solid elements (Solid187) and 127861 nodes. Solid187, which is a higher-order 3-D, 10-node element and well suited to modeling irregular meshes, was used in the model. The element which has plasticity, hyper elasticity, creep, stress stiffening, large deflection, and large strain capabilities, is defined by 10 nodes having three degrees of freedom at each node [26].

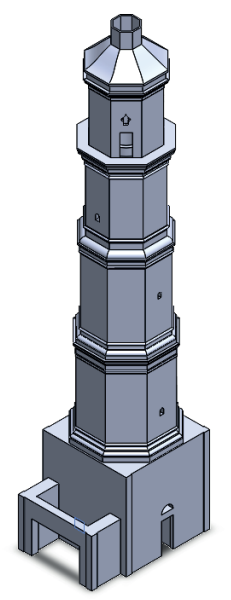

(a)

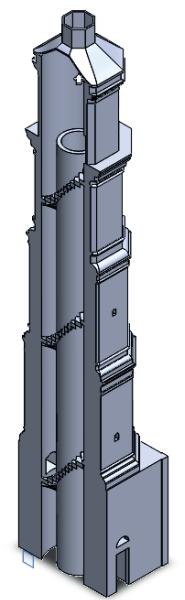

(b)



(c)
Fig. 4 Solid models of the tower (a) SolidWorks model, (b) Section of the tower, (c) Finite element model 


\subsection{Material characteristics}

Details such as the fact that historic buildings have been exposed to abrasive environmental conditions for many years, the deterioration of building materials, different mechanical properties of different stone samples even though they come from the same quarry, make it difficult to determine the mechanical properties of materials used in historic buildings. According to the information provided by Tokat Municipality, no study has been conducted to determine the material properties of the building. Since it is not allowed to take core samples to determine the material properties of the stone used in the tower, the non-destructive testing method and material properties reported in the literature were used for the material model of the analyzes. To determine the compressive strength of the cut stone used in the tower, N-type Schmidt hammer, a non-destructive testing device, was used. The impact energies of N-type Schmit hammers are 2.207 Nm and they can be used for the determination of compressive strength between 10 and $80 \mathrm{MPa}$, according to the manual of the testing device. The rebound numbers and average hardness values obtained, and the corresponding compressive strength are shown in Table 1. Accordingly, the average strength of the cut stone was determined to be $31.67 \mathrm{MPa}$.

Material properties of dry joint masonry walls such as compressive strength and elastic modulus can be determined in analogy to jointed rock masses using the empirical equations as proposed by Tsoutrelis and Exadaktylos [32]. One of the studies in which this approach was used was successfully concluded by Demir and Ilki [33].

$$
\begin{aligned}
& f_{k}=\left[e^{(-0.3117 \times L \times f)}\right] \times f_{b} \\
& L=\sqrt[3]{(l \times h \times t)}
\end{aligned}
$$

$L$ is the effective length given by Eq. (2), where $l, h$ and $t$ represent the width, height, and thickness of the wall, respectively. In Eq. (1), $f_{k}, f_{b}$, and $f$ represent the combined

Table 1 Schmidt hammer results

\begin{tabular}{lccccc}
\hline Rebound & $\begin{array}{c}\mathrm{fb} \\
(\mathrm{MPa})\end{array}$ & Rebound & $\begin{array}{c}\mathrm{fb} \\
(\mathrm{MPa})\end{array}$ & Rebound & $\begin{array}{c}\mathrm{fb} \\
(\mathrm{MPa})\end{array}$ \\
\hline 30 & 28 & 44 & 48 & 28 & 25 \\
40 & 42 & 32 & 31 & 42 & 45 \\
28 & 25 & 30 & 28 & 34 & 33 \\
26 & 23 & 26 & 23 & 32 & 31 \\
34 & 33 & 38 & 39 & 30 & 28 \\
24 & 20 & 28 & 25 & 32 & 31 \\
30 & 28 & 30 & 28 & 26 & 23 \\
& & & & \multicolumn{3}{c}{ Mean 31.67 4.99} \\
\hline
\end{tabular}

compressive strength of the wall, the compressive strength of the stone, and the crack density, respectively. The crack intensity factor $(f)$ and the effective length $(L)$ are calculated using the wall segment of the north facade given in Fig. 5.

$$
\begin{aligned}
& f=\frac{4.75 \times 1.38 \times 1.01+3 \times 2.62 \times 1.01}{1.01 \times 1.38 \times 2.62}=3.99 \mathrm{~m}^{2} / \mathrm{m}^{3} \\
& L=\sqrt[3]{1.01 \times 1.38 \times 2.62}=1.54 \\
& f_{k}=e^{(-0.3117 \times 1.54 \times 3.99)} \times 31.67=4.52 \mathrm{MPa}
\end{aligned}
$$

The compressive strength of the wall is calculated as 4.52 MPa by means of Eq. (1). The elastic modulus is defined as $3390 \mathrm{MPa}$ using the suggested formula in Turkish Building Earthquake Code (TBDY2018 [34]). The suggested formula is given in Eq. (3) below.

$$
E_{m}=750 \times f_{k}
$$

Furthermore, the tensile strength of masonry can be ranged between 5 and $20 \%$ of its compressive strength [15]. In this study, the tensile strength of the stone was taken to be $0.3 \mathrm{MPa}$.

The material model used was the Willam-Warnke five-parameter model $\left(f_{t}, f_{c}, f_{c b}, \sigma_{h}^{a}, f_{1}, f_{2}\right)$, in which the failure surface of the material is formed using the tensile and compressive strengths [35]. In the model $f_{t}, f_{c}, f_{c b}, \sigma_{h}^{a}, f_{1}$ and $f_{2}$ represents the ultimate uniaxial tensile strength, ultimate uniaxial compressive strength, ultimate biaxial compressive strength, ambient hydrostatic stress state, ultimate compressive strength for a state of biaxial compression superimposed on hydrostatic stress state $\sigma_{h}^{a}$, ultimate compressive strength for a state of uniaxial compression superimposed on hydrostatic stress state $\sigma_{h}^{a}$, respectively. However, the failure surface can be specified with a minimum of two constants, $f_{t}$ and $f_{c}$, while the other three constants are by default $f_{c b}=1.2 f_{c}, f_{1}=1.45 f_{c}, f_{2}=1.725 f_{c},[26,35]$. In most cases the hydrostatic stress is limited to $\sqrt[3]{f_{c}}$. The uniaxial stressstrain state of the material model is given in Fig. 6.

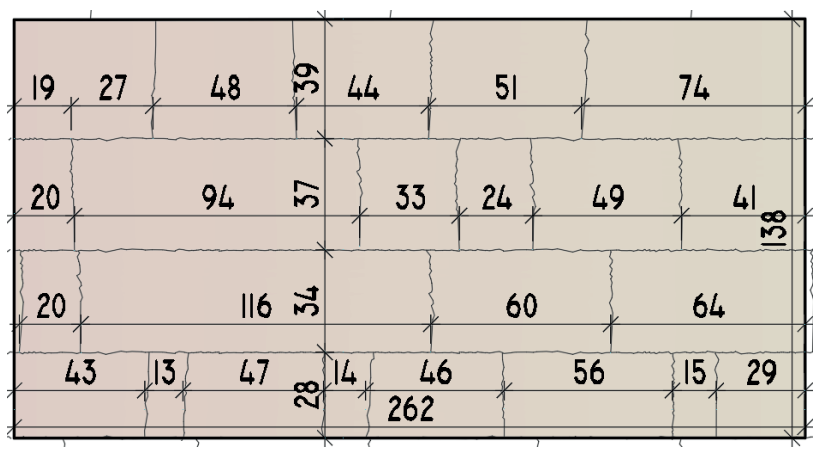

Fig. 5 Wall segment of north facade of the base (dimensions in $\mathrm{cm}$ ) 


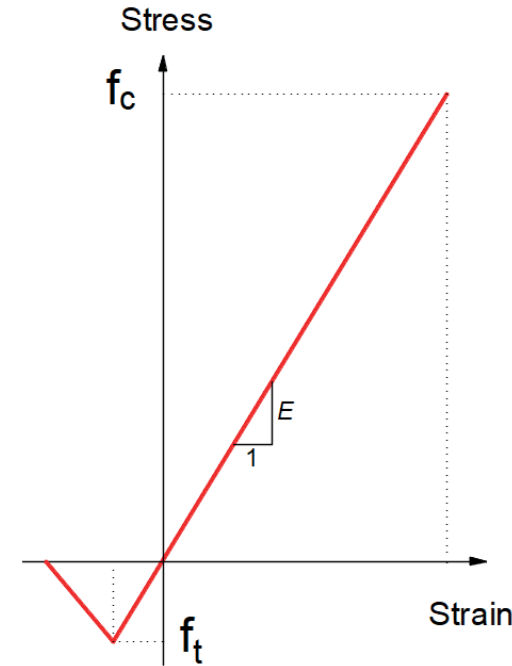

Fig. 6 Uniaxial stress state of the material model

\subsection{Non-linear static analysis}

The material and geometric non-linearity were taken into account in the static analysis. The total weight of the clock tower is $7020 \mathrm{kN}$. The equivalent von-Mises stress and total deformation gradients of the tower are given in Fig. 7. The opening on the south side of the first octagonal block on the square base was subjected to a maximum stress of $0.71 \mathrm{MPa}$ at its edges near the outer surface. Stress concentrations are observed at the junction between the square base and the octagonal body. The tower experienced a total deformation of $1.6 \mathrm{~mm}$ at the body above the balcony. It is considered that the tower does not pose any risk under vertical loads as expected.

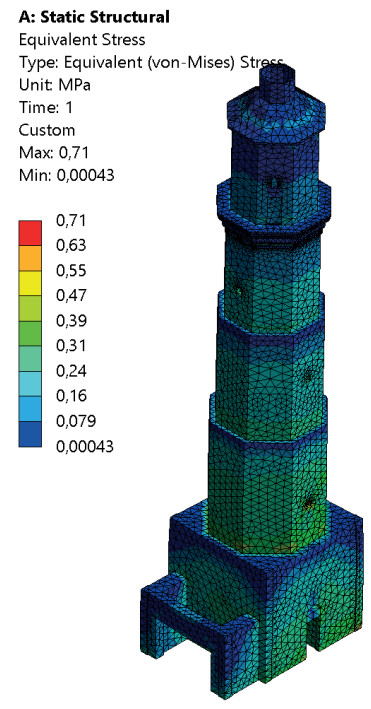

(a)

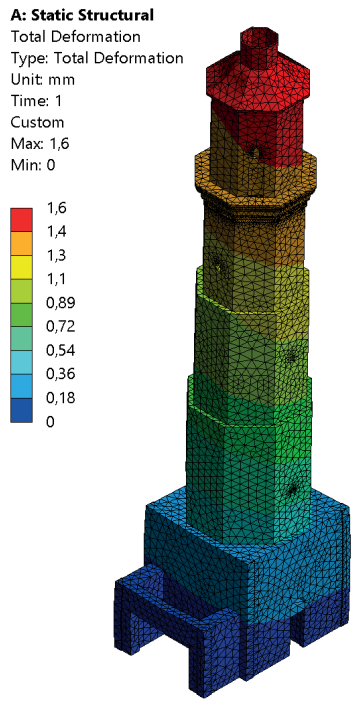

(b)
Fig. 7 Stress and deformation distribution under gravity load (a) Von Mises stress (MPa), (b) Total deformation (mm)

\subsection{Modal analysis}

Modal analysis is the common dynamic simulation for many other dynamic analyzes and shows how the structure will respond to different types of dynamic loading. Since the frequencies and mode shapes depend on the distribution of mass and stiffness in the structure, a pre-stressed modal analysis based on the non-linear static analysis was performed in the study. The vibration mode shapes of the first eight modes, which contribute more to the effective mass participation ratios, are shown in Fig. 8. The first and third vibration modes have translational characteristics in the x-direction with a frequency of 2.58 and $8.33 \mathrm{~Hz}$, respectively. Also, the second and the fourth vibration modes have translational properties in the z-direction with a frequency of 2.65 and $8.47 \mathrm{~Hz}$, respectively. Since the tower has a symmetrical body shape except for the shop extension at the bottom, the translational vibration characteristics in the $\mathrm{x}$ - and $\mathrm{z}$-directions are close to each other. The first mode shape, the fundamental vibration mode, is a translational

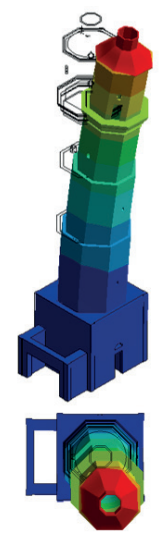

(a)

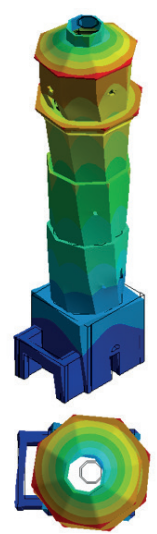

(e)

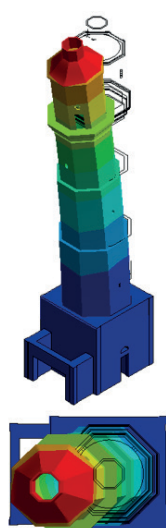

(b)

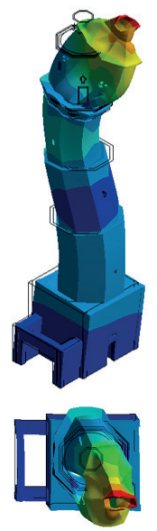

(f)

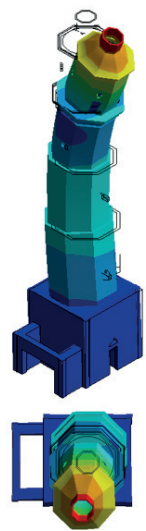

(c)



(g)



(d)

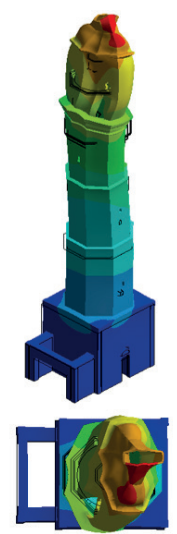

(h)
Fig. 8 Vibration mode shapes and frequencies (a) $2.58 \mathrm{~Hz}$, (b) $2.65 \mathrm{~Hz}$, (c) $8.33 \mathrm{~Hz}$, (d) $8.47 \mathrm{~Hz}$, (e) $11.42 \mathrm{~Hz}$, (f) $15.86 \mathrm{~Hz}$, (g) $16.13 \mathrm{~Hz}$, (h) $16.48 \mathrm{~Hz}$ 
mode shape in the $\mathrm{x}$-direction (N-S) formed by the combination of slight participation in the z-direction (E-W) and vice versa for the second mode shape. The fifth mode shape is under the influence of torsion. The modal participation exceeds $90 \%$ in the first 15 modes.

\subsection{Seismic data for analysis}

Tokat lies on the east-west trending North Anatolian Fault Zone (NAFZ), one of the riskiest faults in Anatolia, which extends between Muş in the east and Sakarya in the west for a distance of $1150 \mathrm{~km}$. The North Anatolian Fault, which has produced very strong earthquakes in history, is a strike-slip active fault. Since 1900, seven earthquakes with magnitudes of 5 and above occurred in Tokat and its vicinity (Fig. 9). In 1916 and 1942, two earthquakes with a magnitude greater than 7 occurred [36]. Unfortunately, there are no acceleration records for these earthquakes.

For the area where the tower was built, the peak ground acceleration for the 475 -year return period is given as $0.316 \mathrm{~g}$, according to the Earthquake Hazard Map of Turkey prepared by the Disaster and Emergency Management Presidency (AFAD) [37]. According to the geotechnical investigations conducted in the region, the site of the structure was identified as medium compact sand or gravel, which corresponds to class ZD in TBDY2018 [34]. The seismic intensity map of the zone is shown in Fig. 10. The portion of the NAFZ between Erzincan and Niksar moved during the 1939 earthquake (Surface wave magnitude $\mathrm{Ms}=7.9$ ), creating a $340 \mathrm{~km}$ long surface fault [37].

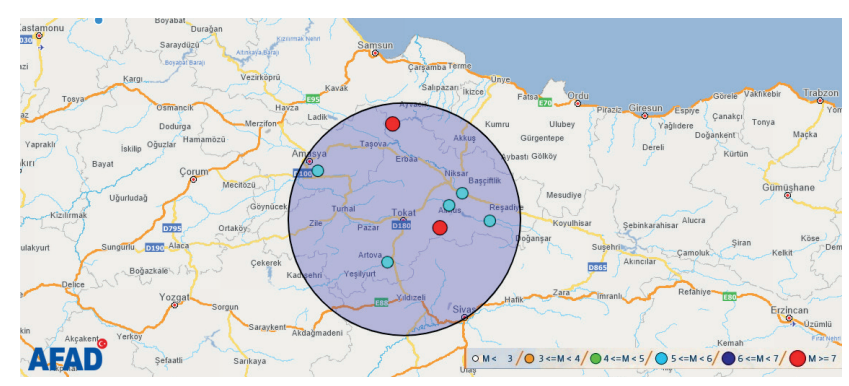

Fig. 9 Earthquakes $M>5$ in Tokat and its surroundings [36]

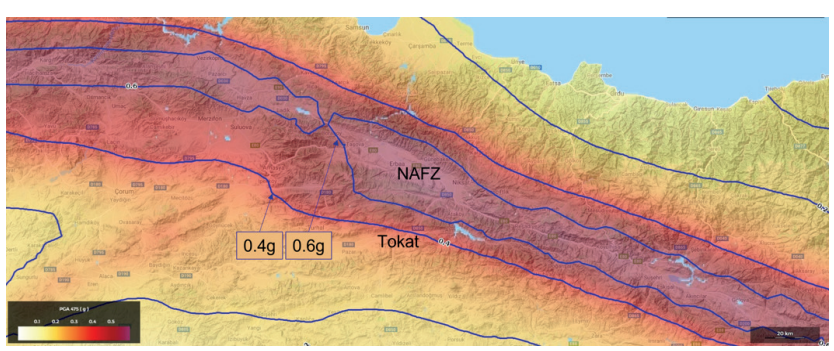

Fig. 10 Seismic intensity map of the region [37]
Acceleration records of the Erzincan earthquake (Moment magnitude $\mathrm{Mw}=6.6$, depth $22.6 \mathrm{~km}$, Peak ground acceleration PGA $=479.57 \mathrm{~cm} / \mathrm{s}^{2}(0.489 \mathrm{~g})$, site classification B, epicentral distance $12.83 \mathrm{~km}$ ), which occurred in 1992, were used for time history analysis. Since the ground motion bi-directionally affects the building, the N-S (North-South) and E-W (East-West) components of the earthquake records were used. First, the original accelerograms were scaled to the design spectrum considering the earthquake risk and local ground conditions at the building site and then used for the analyses [34]. The original and scaled accelerograms of the Erzincan earthquake are given in Fig. 11. The elastic design spectrum which corresponds to the ground motion level of the earthquake with an exceedance probability of $10 \%$ in 50 years (return period of 475 years) and the scaled spectra are shown in Fig. 12. In the time history analyses performed in a nonlinear manner, the proportional viscous damping ratio for stiffness was included as $5 \%$.

\subsection{Non-linear dynamic analysis}

The dynamic base shear force-apex displacement curve of the tower is given in Fig. 13(a). By idealizing this curve, the lateral load capacity and lateral yield displacement of the structure were determined to be approximately $1873 \mathrm{kN}$ and $12.80 \mathrm{~mm}$, respectively. The ratio

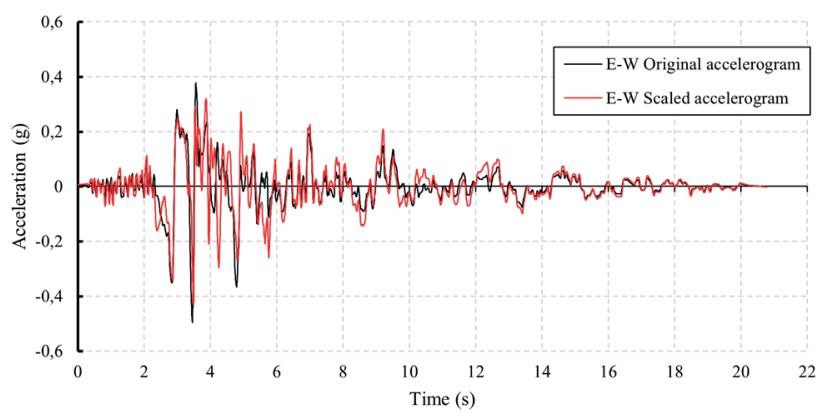

(a)

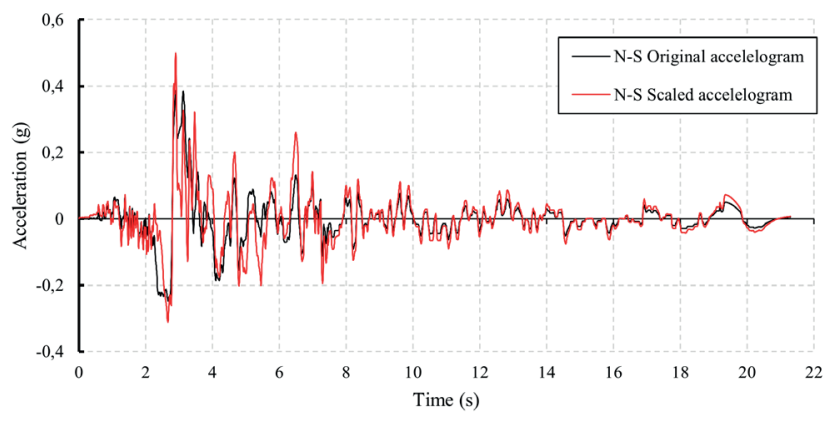

(b)

Fig. 11 The accelerograms of the Erzincan earthquake (a) East-West component, (b) North-South component 




Fig. 12 The design and scaled spectrums

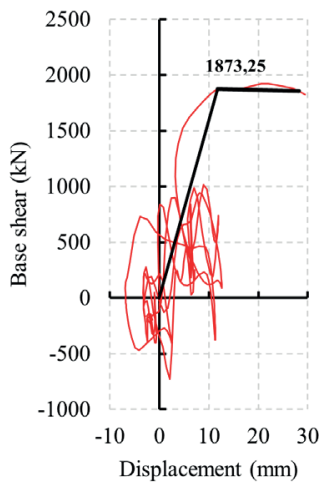

(a)



(b)
Fig. 13 Base shear and displacement curves (a) Base shear displacement curve, (b) Displacement time curve

of maximum base shear force to weight was calculated to be $0.27(\mathrm{~V} / \mathrm{W}=1873.25 / 7020=0.27)$. The study confirming this result was concluded by Brandonisio et al. [38]. In their study of churches damaged in the 2009 L'Aquila earthquake in Italy, the base shear coefficient (the ratio of base shear to the weight of the building) was found to vary between $20 \%$ and $30 \%$. Considering the spectral acceleration of $0.9 \mathrm{~g}$ given in Fig. 12, and the base shear to weight ratio it can be concluded that the structure will be damaged under the earthquake load. It can also be seen from the displacement time curves in Fig. 13(b) that the lateral yield displacement is about $13 \mathrm{~mm}$.

The displacement distributions obtained from the dynamic analysis are shown in Fig. 14. In Fig. 14, values above $13 \mathrm{~mm}$, which is the lateral yield displacement point, are shown in the same color to better observe the time-dependent change in displacements. From the onset of ground motion to 2.5 seconds, the displacements remain within elastic limits except for the top of the tower. The maximum displacement in the structure at 2.5 seconds was calculated to be $14 \mathrm{~mm}$ at the top of the tower. Once this time limit is exceeded, it is seen that the displacements in the structure exceed the critical values in a short time. At 2.65 seconds, the entire body above the balcony level has been exceeded



(a)

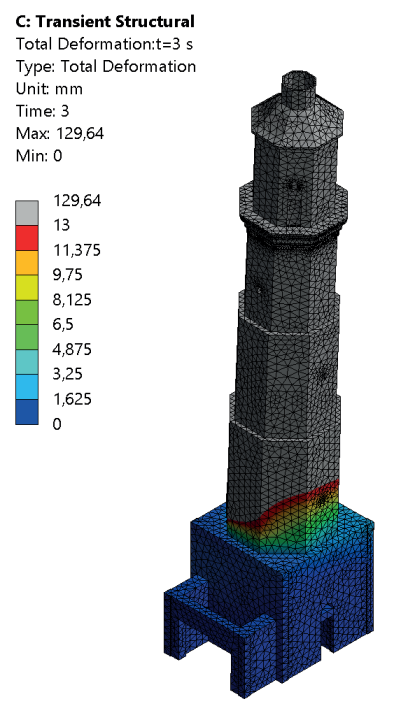

(c)

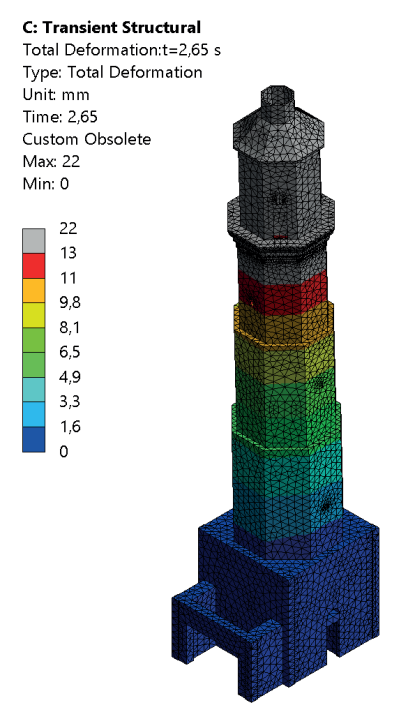

(b)



(d)
Fig. 14 Displacement distribution (a) $t=2.5 s$, (b) $t=2.65 s$, (c) $t=3 s$, (d) $\mathrm{t}=4 \mathrm{~s}$

the lateral yield displacement due to the plastic deformations. It is concluded that all octagonal bodies on the square base are severely damaged in the first 4 seconds of ground motion. Furthermore, it can be stated that masonry structures behave rigidly until their strength is exceeded, and cracks and damage develop rapidly after the strength is exceeded. The maximum lateral displacement at the top of the clock tower was calculated to be $194.63 \mathrm{~mm}$. This lateral displacement corresponds to a drift ratio of $0.59 \%$ $[(194.63 / 33000) \times 100=0.59 \%]$.

The path of the horizontal displacement of node 9458 which is a node above balcony level and the time history trace of the same node along $\mathrm{x}$ and $\mathrm{z}$-directions are given in Fig. 15. When examining Fig. 15(a), it can be concluded 


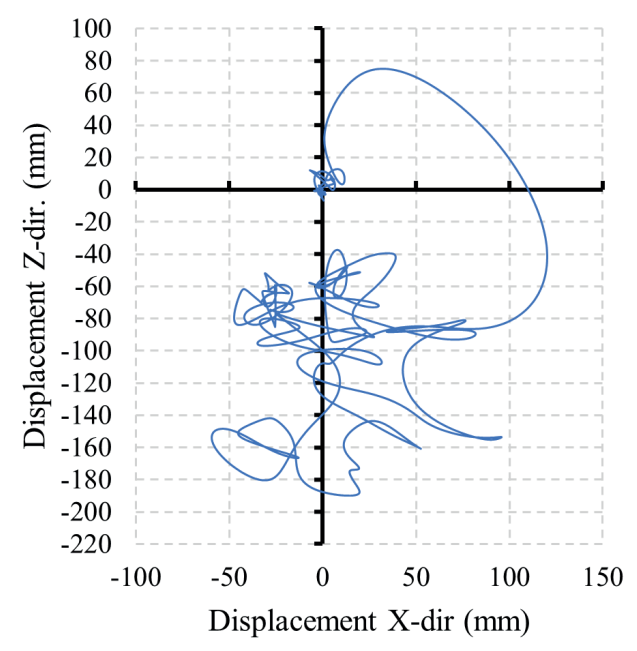

(a)

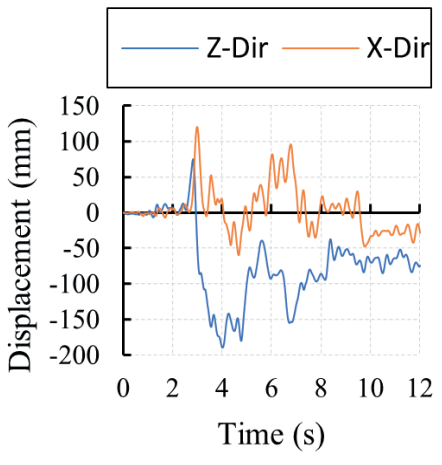

(b)
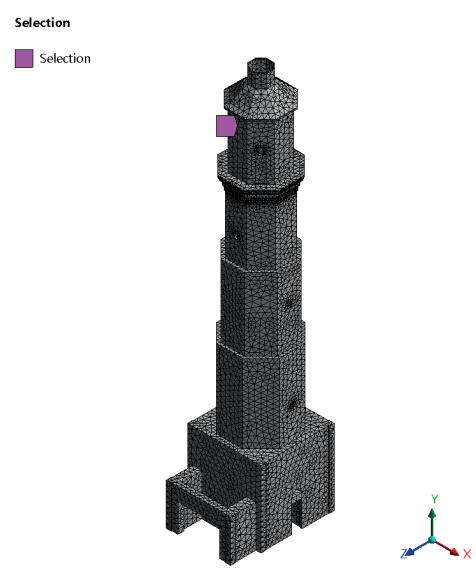

(c)

Fig. 15 Horizontal displacement characteristics of node 9458 (a) Path of the horizontal movement, (b) Time history trace, (c) Node 9458

that the magnitudes of the oscillations in the $\mathrm{x}$ and $\mathrm{z}$-directions reach about 120 and $190 \mathrm{~mm}$, respectively. It can also be seen from the same figure that the reference origin for displacements changes with a rotation about the vertical axis after the elastic limit is exceeded. In Fig. 15(b), when the time history trace of the same point is examined in the $\mathrm{x}$ and $\mathrm{z}$-directions, it is seen that residual displacements due to plastic deformation occur in both directions. Node 9458 in the numeric model can be seen in Fig. 15(c).

The plastic deformation distribution at the end of the ground motion can be seen in Fig. 16. It is seen that plastic deformations are concentrated between the square base and the first octagonal body, and in the transition sections between each octagonal body. Moreover, plastic deformations appear to propagate upwards on the first octagonal body. In addition, plastic deformations were also determined in the parts of the square base close to the fixed support. It can be seen from Fig. 16 that plastic deformations are more limited in the bodies above the balcony level. Considering the plastic deformations revealed by the square base and the octagonal body just above it, it is concluded that the clock tower could be severely damaged or completely collapsed in an earthquake of this magnitude.

\section{Conclusions}

This study addresses the issue of determining the lateral load capacity of a monumental masonry clock tower subjected to earthquake load using non-linear dynamic analysis. For this purpose, the detailed procedure of seismic assessment is presented sequentially in the study. The assessment procedure consists of finite element model, material characterization, linear and non-linear static, and dynamic structural analyzes. The seismicity of the region is discussed in detail before the non-linear dynamic analysis. The combined compressive strength of the wall was determined in analogy to jointed rock masses, using the empirical equations in which the effective compressive strength of the stone and the crack density on the wall were employed. In the non-linear static analysis, the structure was evaluated through stresses and displacements, and risk situations were discussed for gravity loads. The total displacement and equivalent von-Mises stress in the tower under gravity loads were calculated as $1.6 \mathrm{~mm}$ and $0.71 \mathrm{MPa}$, respectively. The calculated stress and displacement values reveal that the tower does not pose any risk

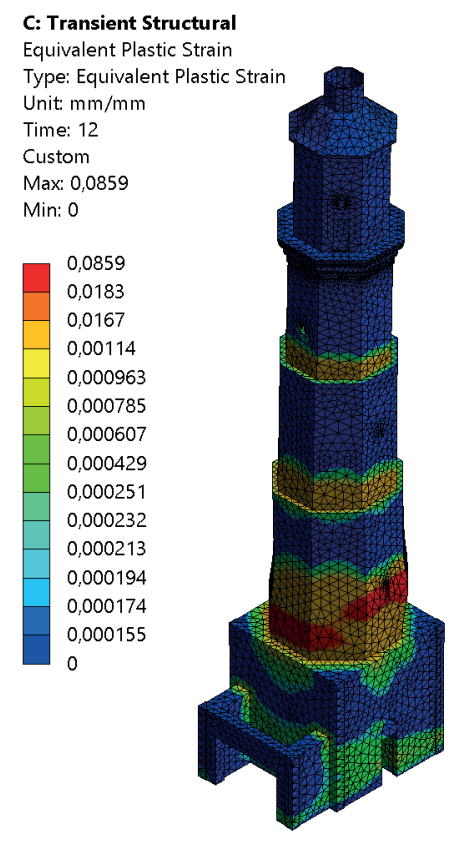

Fig. 16 Plastic deformations 
under vertical loads as expected. Although different stress results have been reported in the static analyzes of the studies in the literature, almost none of the masonry towers are at risk under gravity loads.

The modal analysis is the common dynamic simulation for many other dynamic simulations, and it gives engineers how the structure will respond to different types of dynamic loads. The vibrational properties of the tower such as natural frequencies and mode shapes were determined and discussed by modal analysis. Fundamental vibration frequencies and corresponding periods for the $\mathrm{x}$ and z-directions were calculated as 2.58 and $2.65 \mathrm{~Hz}, 0.39 \mathrm{~s}$, and $0.38 \mathrm{~s}$, respectively. While in the analysis of masonry towers, which are similar in height and plan dimensions, using macro modeling technique and fixed base approach, natural vibration frequencies are reported close to these values $[14,39]$.

Finally, the non-linear time history analysis was performed in which the scaled ground motion is applied bi-directionally. Accordingly, the maximum base shear force to weight ratio was calculated as 0.27 . Considering this ratio, it is concluded that the structure will suffer severe damage in an earthquake with a $10 \%$ probability of exceedance in 50 years, which is called design earthquake. The design earthquake predicts that the structure will be subjected to a spectral acceleration of $0.9 \mathrm{~g}$. In addition, the maximum lateral displacement corresponding to the $0.59 \%$ drift ratio supports this inference. At this point, it should be noted that the FEMA356 [40] standard specifies a $0.4 \%$

\section{References}

[1] Acun, H. "Osmanlı imparatorluğu saat kuleleri" (Clock towers of the Ottoman Empire), Atatürk Kültür Merkezi, Ankara, Turkey, 2011. (in Turkish)

[2] Cansever, M. "Türkiye'nin kültür mirası: 100 saat kulesi" (Turkey's cultural heritage: 100 clock towers), NTV Yayınları, Istanbul, Turkey, 2009. (in Turkish)

[3] Tesei, C., Ventura, G. "A unilateral nonlocal tensile damage model for masonry structures", Procedia Structural Integrity, 2, pp. 2690-2697, 2016.

https://doi.org/10.1016/j.prostr.2016.06.336

[4] Bartoli, G., Betti, M., Galano, L., Zini, G. "Numerical insights on the seismic risk of confined masonry towers", Engineering Structures, 180, pp. 713-727, 2019.

https://doi.org/10.1016/j.engstruct.2018.10.001

[5] Valente, M., Milani, G. "Non-linear dynamic and static analyses on eight historical masonry towers in the North-East of Italy", Engineering Structures, 114, pp. 241-270, 2016. http://dx.doi.org/10.1016/j.engstruct.2016.02.004 drift ratio as the performance level of collapse prevention. In this case, it can be stated that the tower will exceed the collapse prevention performance level for the design earthquake and will be severely damaged or completely collapsed. Residual displacements due to plastic deformation were calculated at the end of the non-linear analysis. These residual displacements show that the structure has gone beyond the elastic limit and exhibited plastic deformations. Although plastic deformations are mostly concentrated between the square base and the first octagonal body, they were also detected in the transition sections between the octagonal bodies and in the lower parts of the square base. Valente and Milani [41] in their study on eight masonry towers, reported that, except for two of them, the others could not resist a $0.2 \mathrm{~g}$-magnitude of ground motion and were damaged at least along one geometric direction.

As a result, since it is thought that the clock tower will be severely damaged or completely collapsed in such an earthquake, it must be retrofitted with acceptable restoration techniques against possible earthquakes.

Finally, the limitations of the finite element model should be considered in the evaluation of the results. It should be noted that different finite element models may yield different results. For example, it should be known that even just changing the boundary conditions will significantly affect the structural behavior. In addition, many details such as material model, modeling methodology, geometric nonlinearities directly affect the analysis procedure and conclusions in masonry structures.

[6] Bayraktar, A., Şahin, A., Özcan, D.M., Yildirim, F. "Numerical damage assessment of Haghia Sophia bell tower by nonlinear FE modeling", Applied Mathematical Modelling, 34(1), pp. 92-121, 2010 .

https://doi.org/10.1016/j.apm.2009.03.033

[7] Milani, G., Casolo, S., Naliato, A., Tralli, A. "Seismic assessment of a medieval masonry tower in Northern Italy by limit, nonlinear static, and full dynamic analyses", International Journal of Architectural Heritage, 6(5), pp. 489-524, 2012. https://doi.org/10.1080/15583058.2011.588987

[8] D'Altri, A. M., Sarhosis, V., Milani, G., Rots, J., Cattari, S., Lagomarsino, S., Sacco, E., Tralli, A., Castellazzi, G., de Miranda, S. "Modeling strategies for the computational analysis of unreinforced masonry structures: review and classification", Archives of Computational Methods in Engineering, 27(4), pp. 1153-1185, 2020.

https://doi.org/10.1007/s11831-019-09351-x 
[9] Azzara, R. M., Girardi, M., Iafolla, V., Lucchesi, D. M., Padovani, C., Pellegrini, D. "Ambient vibrations of age-old masonry towers: Results of long-term dynamic monitoring in the historic centre of Lucca", International Journal of Architectural Heritage, 15(1), pp. 5-21, 2021.

https://doi.org/10.1080/15583058.2019.1695155

[10] Bartoli, G., Betti, M., Marra, A. M., Monchetti, S. "A Bayesian model updating framework for robust seismic fragility analysis of non-isolated historic masonry towers", Philosophical Transactions of the Royal Society A, 377, Article number: 20190024, 2019. https://oi.org/10.1098/rsta.2019.0024

[11] Bartoli, G., Betti, M. Marra, A. M., Monchetti, S. "On the role played by the openings on the first frequency of historic masonry towers", Bulletin of Earthquake Engineering, 18(2), pp. 427-451, 2020.

https://doi.org/10.1007/s10518-019-00662-9

[12] Breccolotti, M., Severini, L., Cavalagli, N., Bonfigli, F. M., Gusella, V. "Rapid evaluation of in-plane seismic capacity of masonry arch bridges through limit analysis", Earthquakes and Structures, 15(5), pp. 541-553, 2018. https://doi.org/10.12989/eas.2018.15.5.541

[13] de Silva, F. "Influence of soil-structure interaction on the site-specific seismic demand to masonry towers", Soil Dynamics and Earthquake Engineering, 131, Article number: 106023, 2020. https://doi.org/10.1016/j.soildyn.2019.106023

[14] Diaferio, M., Foti, D., Potenza, F. "Prediction of the fundamental frequencies and modal shapes of historic masonry towers by empirical equations based on experimental data", Engineering Structures, 156, pp. 433-442, 2018.

https://doi.org/10.1016/j.engstruct.2017.11.061

[15] Gönen, S., Soyöz, S. "Seismic analysis of a masonry arch bridge using multiple methodologies", Engineering Structures, 226, Article number: 111354, 2021.

https://doi.org/10.1016/j.engstruct.2020.111354

[16] Özmen, A., Sayın, E. "Seismic Response of a Historical Masonry Bridge under Near and Far-fault Ground Motions", Periodica Polytechnica Civil Engineering, 65(3), pp. 946-958, 2021. https://doi.org/10.3311/PPci.17832

[17] Karaton, M., Aksoy, H. S. "Seismic Damage Assessment of an 891 Years Old Historic Masonry Mosque", Periodica Polytechnica Civil Engineering, 62(1), pp. 126-135, 2018. https://doi.org/10.3311/PPci.10270

[18] Shehu, R. "Implementation of Pushover Analysis for Seismic Assessment of Masonry Towers: Issues and Practical Recommendations", Buildings, 11(2), Article number: 71, 2021. https://doi.org/10.3390/buildings11020071

[19] Pulatsu, B., Gencer, F., Erdogmus, E. "Study of the effect of construction techniques on the seismic capacity of ancient dry-joint masonry towers through DEM", European Journal of Environmental and Civil Engineering, 2020. https://doi.org/10.1080/19648189.2020.1824823

[20] Shehu, R. "Preliminary Assessment of the Seismic Vulnerability of Three Inclined Bell-towers in Ferrara, Italy", International Journal of Architectural Heritage, 2020. https://doi.org/10.1080/15583058.2020.1805045
[21] Valente, M., Milani, G. "Effects of geometrical features on the seismic response of historical masonry towers", Journal of Earthquake Engineering, 22(sup1), pp. 2-34, 2018. https://doi.org/10.1080/13632469.2016.1277438

[22] Milani, G., Valente, M. "Failure analysis of seven masonry churches severely damaged during the 2012 Emilia-Romagna (Italy) earthquake: Non-linear dynamic analyses vs conventional static approaches", Engineering Failure Analysis, 54, pp. 13-56, 2015. https://doi.org/10.1016/j.engfailanal.2015.03.016

[23] Milani, G., Valente, M. "Comparative pushover and limit analyses on seven masonry churches damaged by the 2012 Emilia-Romagna (Italy) seismic events: Possibilities of non-linear finite elements compared with pre-assigned failure mechanisms", Engineering Failure Analysis, 47, pp. 129-161, 2015. https://doi.org/10.1016/j.engfailanal.2014.09.016

[24] Seka Mimarlık "Tokat clock tower restoration project", [online] Available at: https://www.sekamimarlik.com.tr/portfolio-item/ tokat-saat-kulesi-restorasyon-projesi/, [Accessed: 24 August 2021]

[25] Briccola, D., Bruggi, M. "Analysis of 3D linear elastic masonry-like structures through the API of a finite element software", Advances in Engineering Software, 133, pp. 60-75, 2019. https://doi.org/10.1016/j.advengsoft.2019.04.009

[26] ANSYS "Engineering Simulation \& 3D Design Software", [computer program] Available at: https://www.ansys.com/, [Accessed: 25 November 2021]

[27] SolidWorks "Modelling Software", [computer program] Available at: https://www.solidworks.com/, [Accessed: 15 May 2021]

[28] Gentile, C., Saisi, A. "Ambient vibration testing of historic masonry towers for structural identification and damage assessment", Construction and Building Materials, 21(6), pp. 1311-1321, 2007. https://doi.org/10.1016/j.conbuildmat.2006.01.007

[29] Iervolino, I., Spillatura, A., Bazzurro, P. "Seismic reliability of code-conforming Italian buildings", Journal of Earthquake Engineering, 22(sup2), pp. 5-27, 2018. https://doi.org/10.1080/13632469.2018.1540372

[30] Jalayer, F., Ebrahimian, H., Miano, A., Manfredi, G., Sezen, H. "Analytical fragility assessment using unscaled ground motion records", Earthquake Engineering \& Structural Dynamics, 46(15), pp. 2639-2663, 2017. https://doi.org/10.1002/eqe.2922

[31] Manzini, C.F., Magenes, G., Penna, A., da Porto, F., Camilletti, D., Cattari, S., Lagomarsino, S. "Masonry Italian code-conforming buildings. Part 1: case studies and design methods", Journal of Earthquake Engineering, 22(sup2), pp. 54-73, 2018. https://doi.org/10.1080/13632469.2018.1532358

[32] Tsoutrelis, C. E., Exadaktylos, G. "Effect of rock discontinuities on certain rock strength and fracture energy parameters under uniaxial compression", Geotechnical \& Geological Engineering, 11(2), pp. 81-105, 1993. https://doi.org/10.1007/BF00423337

[33] Demir, C., Ilki, A. "Characterization of the materials used in the multi-leaf masonry walls of monumental structures in Istanbul, Turkey", Construction and Building Materials, 64, pp. 398-413, 2014.

https://doi.org/10.1016/j.conbuildmat.2014.04.099 
[34] TBDY2018 "Turkish building earthquake regulation", Disaster and Emergency Management Authority (AFAD), Ankara, Turkey, 2018.

[35] Willam, K. J., Warnke, E. D. "Constitutive model for the triaxial behaviour of concrete", presented at Seminar on "Conrete Structures Subjected to Triaxial Stresses", Bergamo, Italy, May, 17-19, 1974.

[36] AFAD "1900-20XX Earthquake Catalog $(\mathrm{M}>=4)$ ", [online] Available at: https://deprem.afad.gov.tr/depremkatalogu?lang=en [Accessed: 1 June 2021]

[37] AFAD "Earthquake Hazard Maps Interactive Web Applications", [online] Available at: https://tdth.afad.gov.tr/TDTH/main.xhtml [Accessed: 10.10.2021]

[38] Brandonisio, G., Lucibello, G., Mele, E., De Luca, A. "Damage and performance evaluation of masonry churches in the 2009 L'Aquila earthquake", Engineering Failure Analysis, 34, pp. 693-714, 2013. https://doi.org/10.1016/j.engfailanal.2013.01.021
[39] Cakir, F., Uysal, H. "Seismic Performance of Historical Masonry Clock Tower with Adjacent Walls", Earthquakes and Structures, 7(2), pp. 217-231, 2014. http://dx.doi.org/10.12989/eas.2014.7.2.217

[40] FEMA356 "Prestandard and Commentary for the Seismic rehabilitation of Buildings", Federal Emergency Management Agency, Washinton, DC, USA, 2000.

[41] Valente, M., Milani, G. "Seismic assessment of historical masonry towers by means of simplified approaches and standard FEM", Construction and Building Materials, 108, pp. 74-104, 2016. https://doi.org/10.1016/j.conbuildmat.2016.01.025 